\title{
LITHOLOGICAL DISTRIBUTION OF RARE EARTH ELEMENTS IN AUTOMORPHIC AND ALLUVIAL SOILS IN THE BREGALNICA RIVER BASIN
}

\author{
Biljana Balabanova ${ }^{1}$, Trajče Stafilov ${ }^{2 *}$, Robert S̆ajn $^{3}$ \\ ${ }^{I}$ Faculty of Agriculture, Goce Delčev University, POB 201, 2000 Štip, Republic of Macedonia \\ ${ }^{2}$ Institute of Chemistry, Faculty of Natural Sciences and Mathematics, Ss. Cyril and Methodius University, \\ POB 162, 1000 Skopje, Republic of Macedonia \\ ${ }^{3}$ Geological Survey of Slovenia, Dimičeva ulica 14, 1000 Ljubljana, Slovenia \\ *trajcest@pmf.ukim.mk
}

\begin{abstract}
The present study gives an overview of the rare earth elements (REEs) distribution in automorphic and alluvial soil (top and sub-soil samples) in the environs of Bregalnica river. The element contents were determined using inductively coupled plasma with mass spectrometry. The content of the light rare earth elements (LREEs) in the whole investigated area ranges from 8.6 to $225 \mathrm{mg} \mathrm{kg}^{-1}$, while the content of the heavy rare earth elements (HREEs) ranges from 0.92 to $33.7 \mathrm{mg} \mathrm{kg}^{-1}$. The distribution of the LREEs (La, $\mathrm{Ce}, \mathrm{Pr}, \mathrm{Nd}, \mathrm{Pm}, \mathrm{Sm}, \mathrm{Eu}$ and $\mathrm{Gd}$ ) is predominantly related to the Quaternary terraces and the Paleogene flysch. The anthropogenic activities that occur in the $\mathrm{Pb}-\mathrm{Zn}$ surroundings and the $\mathrm{Cu}$ mineralization in the investigated area significantly influence the lithological distribution of this geochemical association of elements. On the other hand, the distribution of the HREEs (Tb, Dy, Ho, Er, Th, Yb and Lu) presents a typical geochemical association in the area of the Bregalnica river basin.
\end{abstract}

Keywords: soil; rare earth elements; spatial distribution; ICP-MS; Bregalnica river basin

\section{ЛИТОЛОШКА РАСПРЕДЕЛБА НА РЕТКИ ЗЕМЈЕНИ ЕЛЕМЕНТИ ВО АВТОМОРФНИ И АЛУВИЈАЛНИ ПОЧВИ ОД СЛИВОТ НА РЕКАТА БРЕГАЛНИЦА}

Овој труд дава преглед на дистрибуцијата на ретките земјени елементи (REEs) во автоморфни и алувијални почви (површински и длабински примероци) од сливот на реката Брегалница. Содржината на елементите е одредувана со примена на индуктивно спрегната плазма со масена спектрометрија. Содржината на лесните ретки земјени елементи (LREEs) за целото испитувано подрачје е во областа од $8,6-225 \mathrm{mg} \mathrm{kg}^{-1}$, додека вкупната сума на тешките ретки земјени елементи ( $\Sigma$ HREEs) е во областа од 0,92-33,7 mg kg-1. Дистрибуцијата на LREEs (La, Ce, $\mathrm{Pr}, \mathrm{Nd}, \mathrm{Pm}, \mathrm{Sm}, \mathrm{Eu}$ and Gd) е поврзана со квартарните тераси и палеогениот флиш. Антропогените активности, кои се одвиваат во околината на минерализацијата на $\mathrm{Pb}-\mathrm{Zn}$ и Сu во испитуваното подрачје, значајно влијаат на литогената дистрибуција на оваа геохемиска асоцијација на елементите. Од друга страна, пак, дистрибуцијата на тешките ретки земјени елементи (HREEs $\mathrm{Tb}, \mathrm{Dy}, \mathrm{Ho}, \mathrm{Er}, \mathrm{Th}, \mathrm{Yb}$ and Lu) претставува типична геохемиска асоцијација во подрачјето на сливот на реката Брегалница.

Клучни зборови: почва; ретки земјени елементи; просторна дистрибуција; ICP-MS; слив на реката Брегалница

\footnotetext{
- Dedicated to Academician Gligor Jovanovski on the occasion of his $70^{\text {th }}$ birthday.
} 


\section{INTRODUCTION}

There are 17 rare earth metals (REMs) or rare earth elements (REEs), comprising the elements La, Ce, Pr, Nd, Pm, Sm, Eu, Gd, Tb, Dy, $\mathrm{Ho}, \mathrm{Er}, \mathrm{Tm}, \mathrm{Yb}, \mathrm{Lu}, \mathrm{Sc}$ and Y. Fifteen of the REMs constitute a group of elements called lanthanides and are found between the atomic numbers 51 and 71 in the periodic table of elements. Beginning with the atomic number 51, the lanthanides include the following elements: $\mathrm{La}, \mathrm{Ce}$, Pr, Nd, Pm, Sm, Eu, Gd, Tb, Dy, Ho, Er, Tm, Yb and $\mathrm{Lu}$. These elements are grouped together because they exhibit similar chemical and physical properties, considered as REEs. REEs possess certain unique but identical physical and chemical properties which make them useful markers of specific geochemical reactions in soil $[1,2]$.

REEs can be accumulated in different areas of the environment following anthropogenic inputs because of the low mobility of these elements [3, 4]. The most plentiful REEs, cerium and yttrium, occur more often in the Earth's crust than lead, molybdenum, or arsenic. Lanthanum and neodymium occur in similar quantities to lead [5], but even thulium, the rarest of the rare earth elements, can be found more often than gold, platinum, or iodine [6]. Approximate values of REE contents are usually in the range of $150 \mathrm{mg} \mathrm{kg}^{-1}$. Promethium, however, has been found only in very small amounts in uranium ore deposits [7].

Under natural conditions, lanthanides exist as oxides, silicates, carbonates, phosphates, and halogen compounds in minerals [8]. The amounts of individual REEs found in different mineral sources vary, yet the similarity in their ionic radius, oxidation state, and general properties results in their universal occurrence in all rare earth minerals. Therefore, not a single known mineral contains only one lanthanide as its major constituent. However, the establishment of the typical lanthanide contents in minerals allows their origins to be determined. This is also used for geochemical research on rock formations [9].

In recent years, REEs have caused widespread concern because of their persistence in the environment [10-13]. In nature, REEs become available to the soil and consequently to plants by leaching from mineral deposits and then entering groundwater [14]. Various studies have reported significant differences in REE concentrations among different types of soil. According to KabataPendias [15], the sum of total rare earth elements (LREE) ranges from 88.9 to $469 \mathrm{mg} \mathrm{kg}^{-1}$, whereas LREEs (La-Ce-Pr-Nd-Sm-Gd) range from 76.2 to
$447 \mathrm{mg} \mathrm{kg}^{-1}$ and HREEs range from 9.2 to $55.2 \mathrm{mg}$ $\mathrm{kg}^{-1}$. Huang et al. [16] estimated that REE oxides enter the soil due to mining activities, resulting in potential soil pollution because of their persistence and toxicity [17].

The presence of excessive REE contents in soils may have serious consequences for rounding ecosystems, groundwater, agricultural productivity, and human health [18]. Under these circumstances, REEs in soil are released and can enter the human body through multiple exposure pathways [19]. On the other hand, REEs, even when present in low contents, present some specific benefits as feed additives and fertilizers for different agricultural species [20]. Because of the abovementioned factors, there is a need for determination of the geochemistry of these elements in the automorphic and alluvial types of soil as there are different geochemical associations in different geographic areas.

The present investigation presents the first attempt to characterize the REE distribution in the automorphic and alluvial soils in the Bregalnica river basin in the eastern part of the territory of the Republic of Macedonia. The geochemical interaction of these elements plays an important role in the lithological distribution of mineral elements.

\section{EXPERIMENTAL}

\subsection{Characterization of the investigated area}

The investigated area is located in the eastern part of the Republic of Macedonia (Fig. 1) and occupies a total area of $\sim 4000 \mathrm{~km}^{2}$, with longitudinal and latitudinal coordinates of $41^{\circ} 27^{\prime}-42^{\circ} 09^{\prime} \mathrm{N}$ and $22^{\circ} 55^{\prime}-23^{\circ} 01 \mathrm{E}$. The region of the examined area is geographically composed of several sub-regions. The area is characterized by two main valleys: Maleševo and Kočani valleys. The average altitude varies from 270 to $1140 \mathrm{~m}$. The average annual temperature is around $10^{\circ} \mathrm{C}$. Prevailing winds in the region are those from the west, with a frequency of $199 \%$ and speed of $2.7 \mathrm{~m} \mathrm{~s}^{-1}$, and those from the east, with a frequency of $124 \%$ and speed of $2.0 \mathrm{~m}$ $\mathrm{s}^{-1}$ [21]. The average annual rainfall is about 500 $\mathrm{mm}$, with large variations from year to year and in different sub-regions [22]. The rainfalls are mostly influenced by the Mediterranean cyclones [21].

Because of industrialization, urbanization, and uncontrolled discharge of wastewater from industry, mining and flotation, there are higher levels of pollution in terms of the introduction of higher contents of certain toxic metals into the soil [23-27]. Pollution is often particularly high in the lower courses, as is the case for the Bregalnica riv- 
er in its lower course through the Kočani valley $[28,29]$.

Since the REEs are fractionated during the weathering process, ores tend to contain either HREEs or LREEs. REEs are mined from a great variety of ores, even in very small amounts [30, 31]. In accordance with the description, the investigated area includes three highly exploited ore deposits: the Sasa $\mathrm{Pb}-\mathrm{Zn}$ mine, with flotation tailings discharged in the Kamenica river environs, the Zletovo $\mathrm{Pb}-\mathrm{Zn}$ mine, with flotation tailings discharged in the Zletovska Reka river, and the Bučim Cu-mine, with flotation tailings discharged in the Lakavica river. All three rivers mentioned are important tributaries of the Bregalnica river.

A generalized geological description of the whole investigated area is provided on the basis of the geological map given by Rakićević et al. [32]. The investigated area occupies a part of the SerboMacedonian massif. The oldest volcanic rocks occur in the areas of Bučim-Damjan-Borov Dol, Kratovo-Zletovo in the Toranica-Sasa, and Delčevo-Pehčevo [33]. These older volcanic rocks are overlain by middle Miocene sedimentary rocks that provide an upper age limit, and thus the age of these oldest volcanic rocks is defined as Oligoceneearly Miocene. The volcanic rocks are andesite, latite, quartz-latite, dacite, and rarely trachyte and rhyolite [33, 34]. According to the generalized geological map, the dominant geological formations are Proterozoic gneisses, granite and shales, Neogene pyroclastites, clastites and vulcanites, and Paleogene flysch.

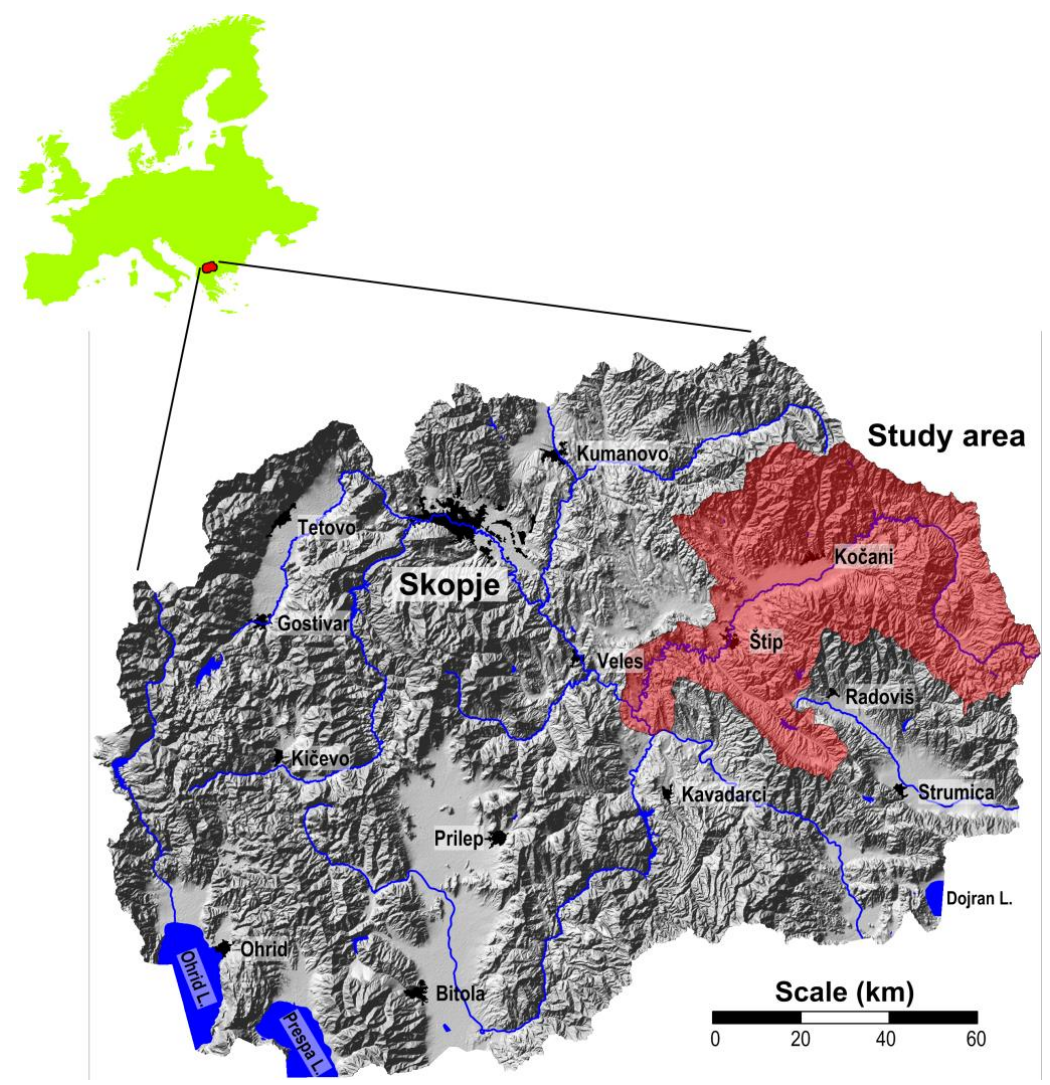

Fig. 1. Location of the investigated area within the territory of the Republic of Macedonia

\subsection{Sampling and sample preparation}

A total of 310 soil samples were collected. Automorphic and alluvial (related to river terraces) types of soil were sampled in the investigated area. The soil samples were collected using a previously adapted sampling network $(5 \times 5 \mathrm{~km})$ as shown in Figure 2. Two soil samples were taken at each location: a sample from the surface layer of the soil (topsoil, 0-5 cm) and a deeper soil layer (subsoil,
20-30 cm). Soil samples were collected according to soil sampling standards $[30,35]$. Each sample was composed of five samples collected within an area of $10 \times 10 \mathrm{~m}$. The collected representative soil samples were air dried at room temperature for one week and passed through a $2 \mathrm{~mm}$ polyethylene sieve to remove plant debris and pebbles. Afterwards, the samples were ground in an agate mortar into fine powder and passed through a $0.100 \mathrm{~mm}$ nylon sieve. In this way the soil samples were to- 
tally dissolved for REE content determination using the wet mineralization procedure with nitric, perchloric, hydrofluoric and hydrochloric acids according to ISO 14869-1:2001 [36].

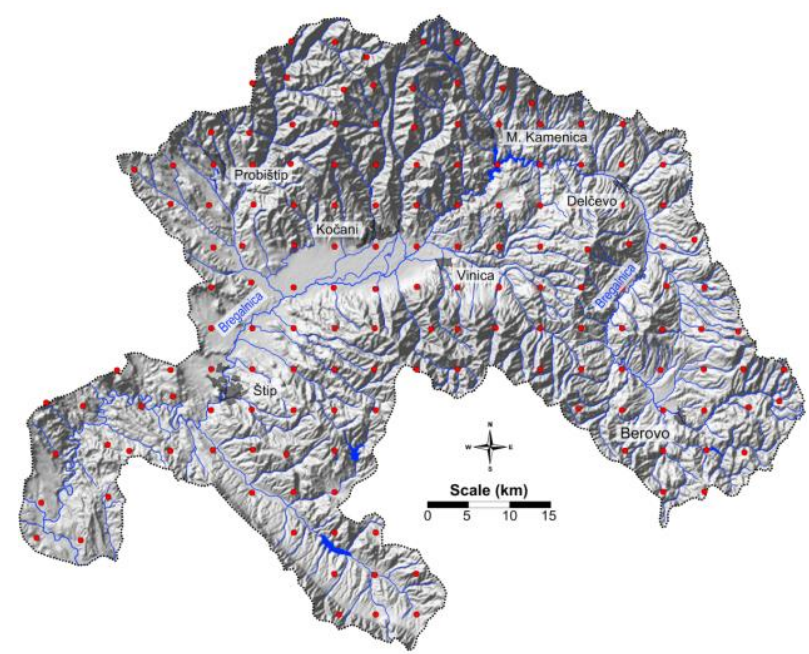

Fig. 2. Soil sampling location network

\subsection{Instrumental operating conditions and specifications}

Fourteen isotopes $\left({ }^{140} \mathrm{Ce},{ }^{163} \mathrm{Dy},{ }^{166} \mathrm{Er},{ }^{153} \mathrm{Eu}\right.$, ${ }^{157} \mathrm{Gd},{ }^{165} \mathrm{Ho},{ }^{139} \mathrm{La},{ }^{175} \mathrm{Lu},{ }^{146} \mathrm{Nd},{ }^{141} \mathrm{Pr},{ }^{147} \mathrm{Sm},{ }^{159} \mathrm{~Tb}$, ${ }^{169} \mathrm{Tm}$ and ${ }^{172} \mathrm{Yb}$ ) were determined using inductively coupled plasma mass spectrometry (ICP-MS, SCIEX Perkin Elmer Elan DRCII, Canada). External calibration was performed by measuring standard solutions containing these 14 rare earth elements at concentrations of $1,5,10,20,50$ and 100 $\mu \mathrm{g}^{-1}$. Mixed solutions containing $\mathrm{Rh}$ and In were used as an internal standard at a concentration of $10 \mathrm{~g} \mathrm{l}^{-1}$. The instrumental operating conditions for the ICP-MS are given in Table 1. Real sensitivity, as determined by the practical limit of detection (LOD), is a function of the signal-to-background ratio (high signal, low background) and the precision of the background measurements (10 blank samples were analyzed). In order to measure the actual sensitivity under helium conditions, signalto-background ratios and three sigma instrumental detection limits (IDLs) were determined in helium mode for the analyzed isotopes (Table 2). Standard solutions were inserted into the sample sequence every 20 samples to verify the sensitivity and repeatability. The recoveries of these 14 rare earth elements were $82.1-105.1 \%$.

\subsection{Data processing}

Statistical software (StatSoft 11.0, Dell, 2012) was used for data processing. Basic descriptive statistical analysis of the values referring to the elements contents was conducted. Data normalization and standardization were performed using the method of Box-Cox transformation [37]. Bivariate statistics were applied for production of a correlation matrix $(p<0.05)$, while T-tests and F-ratios were used for marking the significant differences between the independent and dependent elements' contents (in different sub-areas). The universal kriging method with linear variogram interpolation was applied for the creation of spatial distribution maps [38].

Table 1

Instrument tune and acquisition conditions used

\begin{tabular}{cc}
\hline \hline Instrument & (ICP introduction system) \\
\hline Sampler & Ni (standard) \\
Skimmer & Ni (standard) \\
Nebulizer & MicroMist (standard) \\
Plasma torch & Quartz, 2.5 mm (standard) \\
\hline Integration time & $0.3 \mathrm{~s} \times 1$ point \\
(for all analyzed elements) & 3 \\
Replication & \\
\hline Tune parameters & $1550 \mathrm{~W}$ \\
RF power & $8.5 \mathrm{~mm}^{-1}$ \\
Sample depth & $0.801 \mathrm{~min}^{-1}$ \\
Carrier gas & $0.231 \mathrm{~min}^{-1}$ \\
Makeup gas & $0 \mathrm{~V}$ \\
Extract 1 & $-120 \mathrm{~V}$ \\
Extract 2 & $2 \mathrm{~V}$ \\
Energy discriminator & $\mathrm{He} 5.01 \mathrm{~min}^{-1}$ \\
Reaction gas & $0.58 \%$ \\
CeO/Ce & $2.05 \%$ \\
Ce $\mathrm{e}^{+} / \mathrm{Ce}$ &
\end{tabular}

Table 2

Limit of detection for the analyzed REEs with ICP-MS (in $\mathrm{mg} \mathrm{kg}^{-1}$ )

\begin{tabular}{cccc}
\hline \hline Element & Isotope & LOD & $\boldsymbol{N}(\mathbf{L O D})$ \\
\hline $\mathrm{La}$ & 139 & 0.01 & 308 \\
$\mathrm{Ce}$ & 140 & 0.05 & 308 \\
$\mathrm{Pr}$ & 141 & 0.01 & 308 \\
$\mathrm{Nd}$ & 146 & 0.01 & 308 \\
$\mathrm{Sm}$ & 147 & 0.1 & 307 \\
$\mathrm{Eu}$ & 153 & 0.01 & 308 \\
$\mathrm{Gd}$ & 157 & 0.01 & 308 \\
$\mathrm{~Tb}$ & 159 & 0.01 & 308 \\
$\mathrm{Dy}$ & 163 & 0.01 & 308 \\
$\mathrm{Ho}$ & 165 & 0.01 & 308 \\
$\mathrm{Er}$ & 166 & 0.01 & 308 \\
$\mathrm{Tm}$ & 169 & 0.01 & 307 \\
$\mathrm{Yb}$ & 172 & 0.01 & 308 \\
$\mathrm{Lu}$ & 175 & 0.01 & 307 \\
\hline \hline
\end{tabular}

LOD - limit of detection; N (LOD) - number of samples with contents above LOD 


\section{RESULTS AND DISCUSSION}

The total REE concentrations in the soil samples were determined to have a mean of $79.7 \pm$ $43.4 \mathrm{mg} \mathrm{kg}^{-1}$ and a range of 11 to $254 \mathrm{mg} \mathrm{kg}^{-1}$ for the whole of the investigated area. The values of the elements' contents obtained were entered in a data matrix. The values of the REE contents in the topsoil and the subsoil at every location in the whole of the investigated area were correlated (Table 3). Normalization with application of Box-Cox transformation was used to stabilize the data distri- bution. However, no significant differences were identified between the non-normalized and normalized values of the REE contents (Table 3). Correlations were investigated for the vertical distribution (TS vs. SS) of these elements, and very high $R$ values were obtained $(0.95-1.00)$ for both the transformed and the non-transformed values. Thus, it can be said that the distribution of the REEs shows no significant variation with the lithological vertical distribution, which is not interrupted by significant anthropogenic influence.

Table 3

Median values for REEs contents in topsoil vs. subsoil (average values are given in $\mathrm{mg} \mathrm{kg}^{-1}$ ), $\mathrm{N}=310$

\begin{tabular}{cccccccccc}
\hline \hline Element & TS-(X) & SS-(X) & Cor. $(\mathbf{X})$ & TS-(BC) & SS-(BC) & Cor. (BC) & t (test) & F (ratio) & Sig. \\
\hline Ce & 29 & 31 & 0.95 & 26 & 28 & 0.95 & -0.59 & 1.10 & NS \\
Dy & 3.1 & 3.2 & 0.97 & 2.8 & 2.9 & 0.96 & -0.62 & 1.03 & NS \\
Er & 1.7 & 1.7 & 0.98 & 1.5 & 1.6 & 0.97 & -0.58 & 1.02 & NS \\
Eu & 0.83 & 0.87 & 0.95 & 0.76 & 0.80 & 0.95 & -0.75 & 1.03 & NS \\
Gd & 3.9 & 4.1 & 0.96 & 3.6 & 3.8 & 0.96 & -0.66 & 1.06 & NS \\
Ho & 0.61 & 0.63 & 0.98 & 0.54 & 0.56 & 0.97 & -0.54 & 1.03 & NS \\
La & 13 & 14 & 0.97 & 12 & 12 & 0.97 & -0.39 & 1.08 & NS \\
Lu & 0.27 & 0.27 & 1.00 & 0.25 & 0.25 & 0.99 & -0.33 & 1.00 & NS \\
Nd & 15 & 16 & 0.95 & 14 & 14 & 0.96 & -0.65 & 1.12 & NS \\
Pr & 3.7 & 3.9 & 0.95 & 3.4 & 3.5 & 0.96 & -0.64 & 1.14 & NS \\
Sm & 3.2 & 3.4 & 0.95 & 3.0 & 3.1 & 0.95 & -0.74 & 1.08 & NS \\
Tb & 0.56 & 0.58 & 0.96 & 0.51 & 0.53 & 0.96 & -0.64 & 1.03 & NS \\
Tm & 0.25 & 0.25 & 0.99 & 0.22 & 0.23 & 0.98 & -0.37 & 1.02 & NS \\
Yb & 1.6 & 1.7 & 0.99 & 1.5 & 1.5 & 0.98 & -0.48 & 1.00 & NS \\
\hline \hline
\end{tabular}

TS - topsoil; SS-subsoil; X - average of not transformed values; $\mathrm{BC}$ - average of the Box-Cox transformed values; Cor. - Correlation; NS - not significant differences at $\mathrm{p}<0.05$

In Table 4, the basic statistics for the REEs contents in the topsoil layer are presented. Accordingly, the lanthanum contents vary in the range of $1.6-42 \mathrm{mg} \mathrm{kg}^{-1}$, with median values of $19 \mathrm{mg} \mathrm{kg}^{-1}$ in the Kamenica-Zletovska rivers Quarter terraces (Table 5). Lanthanum distribution is specifically correlated with the older volcanic formations of Paleogene flysch (with a median of $15 \mathrm{mg} \mathrm{kg}^{-1}$ ). Cerium contents vary from 3.6 to $65 \mathrm{mg} \mathrm{kg}^{-1}$ in the topsoil sample, with no significant variations between the contents in the topsoil versus the subsoil layer. Dominant contents of cerium are deposited at the Bregalnica river terraces and KamenicaZletovska rivers terraces very similar to those of La (median value: $43 \mathrm{mg} \mathrm{kg}^{-1}$, Table 5). Praseodymium contributes in the topsoil layer with an average content of $3.4 \mathrm{mg} \mathrm{kg}$. The maximum content of this element reaches $7.8 \mathrm{mg} \mathrm{kg}^{-1}$. Almost all of the elements in the light-lanthanides group show significant content variations in the different sub-areas within the specific geological basin. On the basis of the normalized median values for the isolated samples according to the different geological sub-areas, $F$-values $>2$ were obtained for $\mathrm{La}, \mathrm{Ce}, \mathrm{Pr}, \mathrm{Nd}, \mathrm{Sm}$, and Eu (Table 5).

Although it belongs to the group of REEs, neodymium can hardly be described as rare at all. Its abundance in the Earth's crust is about $38 \mathrm{mg}$ $\mathrm{kg}^{-1}$, which is the second highest among the REEs, following cerium $[39,40]$. In the present case, $\mathrm{Nd}$ occurs dominantly in the alluvial terraces $(21 \mathrm{mg}$ $\mathrm{kg}^{-1}$ ), and its content is $15 \mathrm{mg} \mathrm{kg}^{-1}$ for the whole of the Bregalnica river environs. Median contents of $17 \mathrm{mg} \mathrm{kg}^{-1}$ were found in the samples from the areas with Paleogene flysch as the dominant geological formation. Samarium occurs in the range of $0.43-8.2 \mathrm{mg} \mathrm{kg}^{-1}$, with significant variations in different geologically based areas $(F=2.03)$. This element has the highest correlation (0.99) with $\mathrm{Gd}$ and $\mathrm{Nd}$ (Table 6). 
Table 4

Basic statistics for REEs contents (in $\mathrm{mg} \mathrm{kg}^{-1}$ ) in the top soil layer

\begin{tabular}{ccccccccccccccc}
\hline \hline Element & $\mathbf{X}$ & $\mathbf{X}(\mathbf{B C})$ & $\mathbf{M d}$ & $\mathbf{M i n}$ & $\mathbf{M a x}$ & $\mathbf{P}_{\mathbf{2 5}}$ & $\mathbf{P}_{\mathbf{7 5}}$ & $\mathbf{S}$ & $\mathbf{S x}$ & $\mathbf{C V}$ & $\mathbf{A}$ & $\mathbf{E}$ & $\mathbf{A}(\mathbf{B C})$ & $\mathbf{E}(\mathbf{B C})$ \\
\hline $\mathbf{L a}$ & 13 & 12 & 12 & 1.6 & 42 & 8.7 & 18 & 6.7 & 0.53 & 50 & 0.72 & 1.02 & 0.04 & 0.32 \\
$\mathbf{C e}$ & 30 & 27 & 28 & 3.6 & 65 & 20 & 39 & 14 & 1.1 & 47 & 0.37 & -0.64 & 0.02 & 0.11 \\
$\mathbf{P r}$ & 3.8 & 3.4 & 3.7 & 0.48 & 7.8 & 2.6 & 4.8 & 1.7 & 0.13 & 44 & 0.36 & -0.45 & 0.04 & 0.33 \\
$\mathbf{N d}$ & 15 & 14 & 15 & 1.9 & 34 & 10 & 20 & 6.7 & 0.54 & 43 & 0.40 & -0.19 & 0.04 & 0.46 \\
$\mathbf{S m}$ & 3.3 & 3.1 & 3.2 & 0.43 & 8.2 & 2.3 & 4.3 & 1.4 & 0.11 & 42 & 0.58 & 0.50 & 0.06 & 0.70 \\
$\mathbf{E u}$ & 0.85 & 0.78 & 0.84 & 0.12 & 2.3 & 0.58 & 1.0 & 0.37 & 0.030 & 44 & 0.83 & 1.43 & 0.06 & 0.81 \\
$\mathbf{G d}$ & 4.0 & 3.7 & 3.8 & 0.56 & 11 & 2.9 & 4.8 & 1.7 & 0.13 & 42 & 0.83 & 1.41 & 0.09 & 1.04 \\
$\mathbf{T b}$ & 0.57 & 0.52 & 0.54 & 0.088 & 1.7 & 0.40 & 0.67 & 0.25 & 0.020 & 44 & 1.20 & 2.76 & 0.09 & 1.24 \\
$\mathbf{D y}$ & 3.2 & 2.9 & 2.9 & 0.50 & 10 & 2.2 & 3.8 & 1.5 & 0.12 & 47 & 1.49 & 3.69 & 0.09 & 1.44 \\
$\mathbf{H o}$ & 0.62 & 0.55 & 0.56 & 0.099 & 2.1 & 0.42 & 0.72 & 0.30 & 0.024 & 49 & 1.64 & 4.23 & 0.08 & 1.53 \\
$\mathbf{E r}$ & 1.7 & 1.5 & 1.6 & 0.29 & 5.9 & 1.2 & 2.0 & 0.84 & 0.068 & 49 & 1.64 & 4.12 & 0.08 & 1.55 \\
$\mathbf{T m}$ & 0.25 & 0.23 & 0.23 & 0.043 & 0.82 & 0.17 & 0.29 & 0.12 & 0.010 & 48 & 1.56 & 3.68 & 0.10 & 1.74 \\
$\mathbf{Y b}$ & 1.7 & 1.5 & 1.5 & 0.29 & 5.0 & 1.1 & 2.0 & 0.75 & 0.061 & 46 & 1.41 & 2.94 & 0.09 & 1.55 \\
$\mathbf{L u}$ & 0.27 & 0.25 & 0.25 & 0.046 & 0.74 & 0.18 & 0.33 & 0.12 & 0.009 & 43 & 1.13 & 1.84 & 0.12 & 1.60 \\
\hline \hline
\end{tabular}

$\mathrm{X}$ - average of not transformed values; $\mathrm{BC}$ - average of the Box-Cox transformed values; Md - median; Min - minimum;

$\mathrm{Max}$ - maximum; $\mathrm{P}_{25}-25$ percentile; $\mathrm{P}_{75}-75$ percentile; $\mathrm{S}$ - standard deviation; $\mathrm{Sx}$ - standard error deviation;

$\mathrm{CV}$ - coefficient of variation; A - skewness; E - kurtosis

Europium shows a significant variation depending on the geology of the investigated area $(F$ $=2.46)$. Alluvial terraces are dominant in Eu occurrence $\left(1.2 \mathrm{mg} \mathrm{kg}^{-1}\right)$, with significant variation between the dominant geological units. The HREEs terbium, holmium, thulium and lutetium were found in lower contents compared with the rest of the REEs, with median values of $0.84,0.54$, $0.56,0.23$ and $0.25 \mathrm{mg} \mathrm{kg}^{-1}$, respectively (Table 4). The occurrences of heavy lanthanides ( $\mathrm{Tb}, \mathrm{Dy}$, $\mathrm{Ho}, \mathrm{Er}, \mathrm{Tm}, \mathrm{Yb}, \mathrm{Lu}$ ) did not show statistical variations among the different geological basins in the investigated area (Table 5).

The lithological distribution of the REEs in different environs is often related to the specific formation of soil types and basic geological formations, as elaborated by numerous authors [11, 41, 42]. Cerium, as the most dominant of the REEs, shows a certain variation compared with data from similar investigations; for example, in Australian soil Ce ranges from 21.0 to $120.3 \mathrm{mg}$ $\mathrm{kg}^{-1}$ [41], in Japanese soil it ranges from 2.46 to $116 \mathrm{mg} \mathrm{kg}^{-1}$ [42], and in Swiss forest soil it ranges from 10.4 to $100.8 \mathrm{mg} \mathrm{kg}^{-1}$ [43]. Lanthanum has a very similar distribution; in Australian soil it ranges from 2.7 to $24.3 \mathrm{mg} \mathrm{kg}^{-1}$ [41], while in Japanese soil it ranges from 1.20 to $51.1 \mathrm{mg} \mathrm{kg}^{-1}$, as given by Yoshida et al. [42]. The rest of the elements included in the present study are in line with the world's average trend of distribution, ranging from $\sim 0.1$ to $10 \mathrm{mg} \mathrm{kg}^{-1}[3,11,41-43]$.

The correlation analysis of the normalized values for the REE contents shows significant association of these elements in the whole studied area. The strongest correlations $\left(r^{2}=1.00\right)$ that can be separated from the correlation matrix are the correlations of Dy-Ho, Ho-Er, Tm-Er, Pr-Lu and $\mathrm{Yb}-\mathrm{Tm}$ (Table 6). From the correlation coefficients matrix it can be noticed that significant correlations (for values of $r^{2}>0.95$ ) were obtained for both LREEs and HREEs. Good correlation coefficients $\left(r^{2}>0.7, p<0.05\right)$ exist for most of the REEs (Table 6), so from the data of the correlation matrix it is very hard to distinguish the selective distribution of LREEs from HREEs. The enrichment of LREEs or HREEs is usually distinguished by the calculation of chondrite-normalized REEs [44]. In general, high chondrite-normalized $\mathrm{La} / \mathrm{Yb}$ ratios and $\mathrm{Gd} / \mathrm{Yb}$ ratios lower than 2.0 are criteria for LREE enrichment [44]. In this study, $\mathrm{Gd} / \mathrm{Yb}>$ 2 , which supports the hypothesis that no selective distributions of two groups of REEs exist. This finding was confirmed by the non-significant $F$ value (1.12) obtained for the contents of LREEs versus HREEs.

The distribution of the REE contents was examined according to the different types of soils (automorphic and alluvial) in dependence on the dominant geological formation in the investigated area. Intensive correlation was established $(>0.90)$ among the LREEs on one hand and among the HREEs on the other hand.

As can be seen in Figure 3, the distribution of the $\mathrm{La}, \mathrm{Ce}, \mathrm{Pr}, \mathrm{Nd}, \mathrm{Sm}, \mathrm{Eu}$ and $\mathrm{Gd}$ is marked by a dominant presence in the Kamenica-Zletovska rivers terraces $(\mathrm{K}-\mathrm{Z})$, which is probably a consequence of the $\mathrm{Pb}-\mathrm{Zn}$ mining activities. Furthermore, there is a significant correlation with the 
Paleogene flysch as a dominant geological formation in the lower course of the Bregalnica river Quarter terraces (B-2). The distribution of this group of REEs shows significant differences in their contents in automorphic and alluvial soils in areas with different geological bases (Table 5). Only europium deviates from this assumption, taking into consideration its higher content in the alluvial soil samples collected from the Kamenica and Zletovska rivers $\left(1.1 \mathrm{mg} \mathrm{kg}^{-1}\right)$.

The heavy REEs (Tb, Dy, Ho, Er, Tm, Yb and $\mathrm{Lu}$ ) are concentrated on the Quaternary terrac- es (Fig. 4). The distributions of these elements do not show any significant variations between the areas with different geological formations (Table 5). Even the metamorphic vulcanite rocks do not play any significant role in their distribution. Thus, the automorphic soil from the river terraces presents a lithological archive for these elements. The alluvial soil collected from the upper and lower courses of the Bregalnica river basin, Kamenica river and Zletovska river is characterized by lower contents of HREEs compared with the automorphic soils (Fig. 4).

Table 5

Distribution of REEs in different geologic basin units and sub-areas in the investigated area (median values in $\mathrm{mg} \mathrm{kg}^{-1}$ )

\begin{tabular}{|c|c|c|c|c|c|c|c|c|c|c|c|c|c|c|}
\hline \multirow{2}{*}{$\begin{array}{l}\text { Ele- } \\
\text { ment }\end{array}$} & \multirow{2}{*}{$\begin{array}{l}\text { B-1 } \\
\text { (Q) }\end{array}$} & \multirow{2}{*}{$\begin{array}{l}\text { B-2 } \\
(\mathrm{Q})\end{array}$} & \multirow{2}{*}{$\begin{array}{c}\mathrm{K}-\mathrm{Z} \\
(\mathrm{Q})\end{array}$} & \multirow{2}{*}{$\begin{array}{c}\mathrm{T} \\
(\mathrm{Q})\end{array}$} & \multirow{2}{*}{$\begin{array}{c}\mathrm{S} \\
(\mathrm{Ng})\end{array}$} & \multicolumn{7}{|c|}{ Basic geological formations } & \multirow{2}{*}{$\begin{array}{c}F- \\
\text { ratio }\end{array}$} & \multirow{2}{*}{ Sign } \\
\hline & & & & & & $\begin{array}{c}\text { Pyroclas- } \\
\text { tite }(\mathrm{Ng})\end{array}$ & $\begin{array}{c}\text { Flysch } \\
(\mathrm{Pg})\end{array}$ & $\begin{array}{c}\text { Schist } \\
(\mathrm{Pz})\end{array}$ & $\begin{array}{c}\text { Schist } \\
(\mathrm{R})\end{array}$ & $\begin{array}{c}\text { Schist } \\
(\mathrm{Pt})\end{array}$ & $\begin{array}{c}\text { Gneisses } \\
(\mathrm{Pt})\end{array}$ & $\begin{array}{l}\text { Granite } \\
(\mathrm{Mz}-\mathrm{Pt})\end{array}$ & & \\
\hline La & 12 & 12 & 19 & 18 & 13 & 13 & 15 & 14 & 8.8 & 10 & 11 & 10 & 3.47 & $*$ \\
\hline $\mathrm{Ce}$ & 28 & 27 & 43 & 43 & 28 & 28 & 34 & 29 & 21 & 24 & 25 & 23 & 3.43 & $*$ \\
\hline Pr & 3.5 & 3.3 & 5.2 & 5.1 & 3.4 & 3.6 & 4.1 & 3.6 & 2.9 & 3.1 & 3.3 & 3.0 & 2.59 & $*$ \\
\hline Nd & 14 & 13 & 20 & 21 & 14 & 15 & 17 & 14 & 12 & 13 & 13 & 12 & 2.39 & $*$ \\
\hline Sm & 3.1 & 2.6 & 4.0 & 4.5 & 3.0 & 3.2 & 3.4 & 3.0 & 2.9 & 2.8 & 2.9 & 2.7 & 2.03 & $*$ \\
\hline Eu & 0.86 & 0.69 & 1.1 & 1.2 & 0.75 & 0.92 & 0.85 & 0.72 & 0.80 & 0.69 & 0.71 & 0.67 & 2.46 & $*$ \\
\hline Gd & 4.0 & 3.4 & 4.7 & 5.3 & 3.6 & 3.7 & 4.1 & 3.6 & 3.6 & 3.5 & 3.5 & 3.2 & 1.62 & NS \\
\hline $\mathbf{T b}$ & 0.57 & 0.49 & 0.64 & 0.75 & 0.50 & 0.52 & 0.56 & 0.51 & 0.53 & 0.51 & 0.50 & 0.45 & 1.41 & NS \\
\hline Dy & 3.3 & 2.7 & 3.4 & 4.2 & 2.7 & 2.9 & 3.0 & 2.8 & 3.0 & 2.9 & 2.8 & 2.5 & 1.39 & NS \\
\hline Ho & 0.65 & 0.55 & 0.64 & 0.81 & 0.53 & 0.55 & 0.57 & 0.54 & 0.59 & 0.56 & 0.53 & 0.47 & 1.39 & NS \\
\hline Er & 1.7 & 1.4 & 1.7 & 2.3 & 1.5 & 1.6 & 1.6 & 1.5 & 1.7 & 1.6 & 1.5 & 1.3 & 1.32 & NS \\
\hline $\mathbf{T m}$ & 0.26 & 0.23 & 0.27 & 0.33 & 0.21 & 0.23 & 0.23 & 0.21 & 0.24 & 0.23 & 0.22 & 0.19 & 1.30 & NS \\
\hline $\mathbf{Y b}$ & 1.6 & 1.4 & 1.7 & 2.1 & 1.4 & 1.5 & 1.5 & 1.4 & 1.6 & 1.5 & 1.4 & 1.3 & 1.18 & NS \\
\hline $\mathbf{L u}$ & 0.26 & 0.23 & 0.29 & 0.36 & 0.23 & 0.27 & 0.25 & 0.23 & 0.26 & 0.26 & 0.24 & 0.22 & 1.26 & NS \\
\hline
\end{tabular}

Q - Quarter; Ng - Neogene; Pg - Paleogene; Pz - Paleozoic; R - Rifey (Late Precambrian); Pt - Proterozoic; Mz - Mesozoic; $\mathrm{T}$ - Terraces; $\mathrm{S}$ - Sediment

Table 6

Matrix of correlation coefficients for REEs contents in topsoil samples $\left(N=155, p<0.05, r^{2}>0.70\right)$

\begin{tabular}{|c|c|c|c|c|c|c|c|c|c|c|c|c|c|c|}
\hline $\mathrm{Ce}$ & 1.00 & & & & & & & & & & & & & \\
\hline Dy & 0.77 & 1.00 & & & & & & & & & & & & \\
\hline $\mathrm{Er}$ & 0.70 & 0.99 & 1.00 & & & & & & & & & & & \\
\hline $\mathrm{Eu}$ & 0.84 & 0.92 & 0.89 & 1.00 & & & & & & & & & & \\
\hline Gd & 0.87 & 0.97 & 0.94 & 0.96 & 1.00 & & & & & & & & & \\
\hline Ho & 0.72 & 1.00 & 1.00 & 0.90 & 0.95 & 1.00 & & & & & & & & \\
\hline $\mathrm{La}$ & 0.96 & 0.72 & 0.65 & 0.79 & 0.84 & 0.67 & 1.00 & & & & & & & \\
\hline $\mathrm{Lu}$ & 0.70 & 0.94 & 0.96 & 0.87 & 0.90 & 0.95 & 0.65 & 1.00 & & & & & & \\
\hline $\mathrm{Nd}$ & 0.96 & 0.88 & 0.83 & 0.93 & 0.96 & 0.85 & 0.93 & 0.83 & 1.00 & & & & & \\
\hline $\operatorname{Pr}$ & 0.97 & 0.84 & 0.79 & 0.90 & 0.93 & 0.81 & 0.95 & 0.79 & 1.00 & 1.00 & & & & \\
\hline $\mathrm{Sm}$ & 0.91 & 0.94 & 0.89 & 0.96 & 0.99 & 0.91 & 0.88 & 0.88 & 0.99 & 0.97 & 1.00 & & & \\
\hline $\mathrm{Tb}$ & 0.82 & 0.99 & 0.97 & 0.95 & 0.99 & 0.98 & 0.78 & 0.93 & 0.93 & 0.89 & 0.97 & 1.00 & & \\
\hline $\mathrm{Tm}$ & 0.69 & 0.98 & 1.00 & 0.87 & 0.92 & 0.99 & 0.64 & 0.97 & 0.82 & 0.78 & 0.88 & 0.96 & 1.00 & \\
\hline \multirow[t]{2}{*}{$\mathrm{Yb}$} & 0.69 & $\mathbf{0 . 9 7}$ & 0.99 & $\mathbf{0 . 8 7}$ & 0.92 & 0.98 & 0.65 & 0.99 & $\mathbf{0 . 8 2}$ & $\mathbf{0 . 7 9}$ & $\mathbf{0 . 8 9}$ & 0.95 & 1.00 & 1.00 \\
\hline & $\mathrm{Ce}$ & Dy & $\mathrm{Er}$ & $\mathrm{Eu}$ & $\mathrm{Gd}$ & Ho & $\mathrm{La}$ & $\mathrm{Lu}$ & $\mathrm{Nd}$ & $\mathrm{Pr}$ & $\mathrm{Sm}$ & $\mathrm{Tb}$ & $\mathrm{Tm}$ & $\mathrm{Yb}$ \\
\hline
\end{tabular}



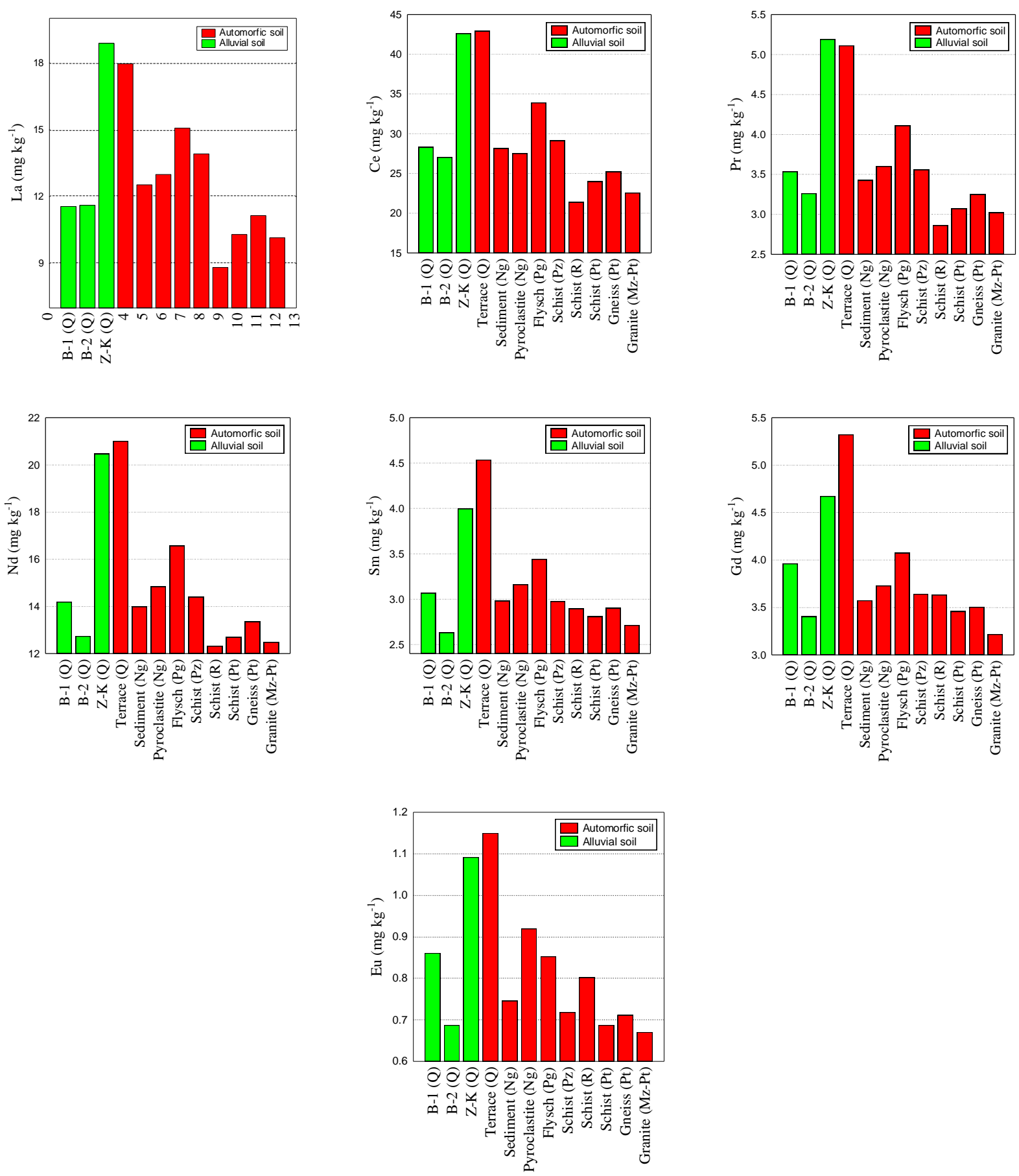

Fig. 3. Distribution of light REEs ( $\mathrm{La}, \mathrm{Ce}, \mathrm{Pr}, \mathrm{Nd}, \mathrm{Sm}, \mathrm{Eu}$ and $\mathrm{Gd}$ ) in different areas with specific geological basin 

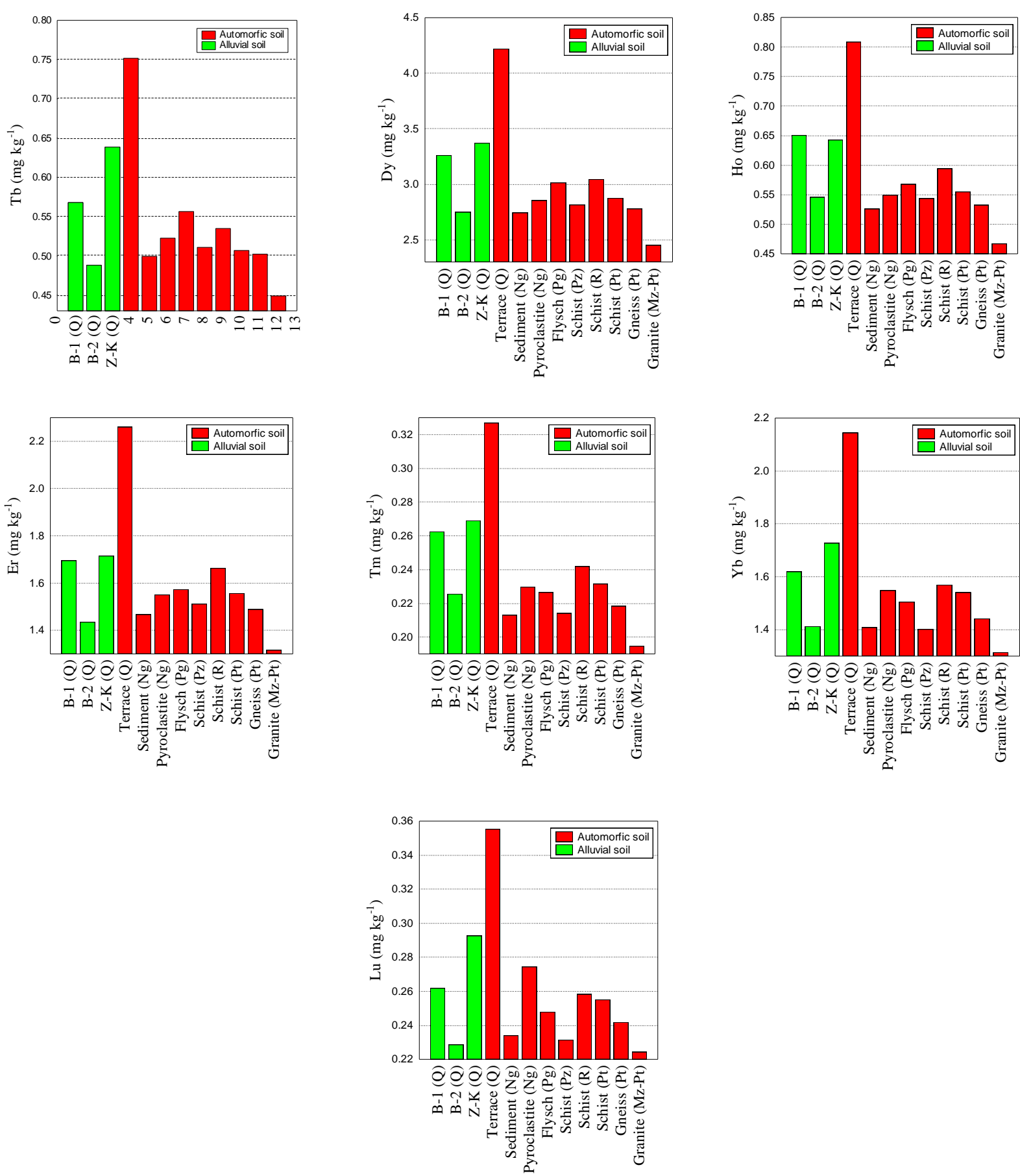

Fig. 4. Distribution of heavy REEs (Tb, Dy, Ho, Er, Tm, Yb and Lu) in different areas with specific geological basin 
Areal distribution maps were made for better visualization of the REE distribution, as shown in Figures 5 and 6. It is obvious that the spatial distribution of the REEs is emphasized in the alluvial and automorphic soils of the Quaternary terraces in the Kočani valley and shows lower intensity in the Maleševo valley. The Kočani valley is represented by Quaternary terraces and contributions of Quaternary alluvium. This is an area with intensively cultivated agricultural land, predominantly used for growing rice. Phosphatic fertilizers added to agricultural soils could thus be a possible source of REEs as well [42]. Certain previous investigations conducted in the Kočani field paddy soil estimated that this soil originated from composite material mostly derived from igneous, volcanic, metamorphic and sedimentary rocks transported by the Bregalnica river and its tributaries. The elevated concentrations of HREEs were explained by the contribution of the mafic and ultramafic lithologies to the soil formation [28]. In the present investigation, the deposition of La-Ce-Pr-Nd-Sm-Eu-Gd was found to be predominant in the Quaternary terraces and the Paleogene flysch. Regarding the contents in the alluvial soil, dominant depositions were detected at the Zletovska Reka river and $\mathrm{Ka}$ menica river. This occurrence is related to the oldest formations, such as Neogene and Paleogene volcanic rocks. These areas are characterized by $\mathrm{Pb}-\mathrm{Zn}$ mineralization. The third isolated deposition of these elements occurs in the $\mathrm{Cu}$-mine environs in the SE part of the investigated area. The enrichment of these elements is influenced by the main ore mineralization (Fig. 5).

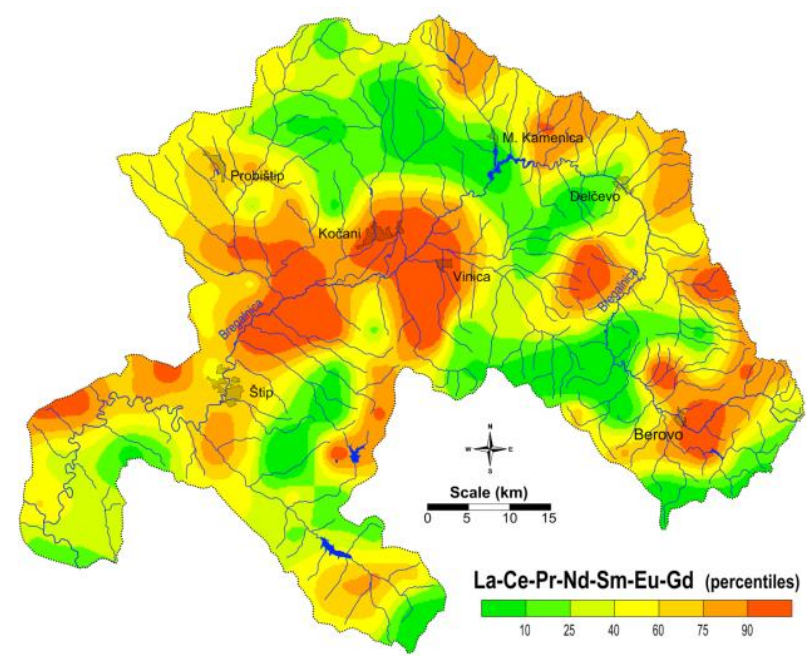

Fig. 5. Spatial distribution of La-Ce-Pr-Nd-Sm-Eu-Gd in the investigated area
The spatial distribution of the HREEs is strongly related to the lithology of the region, with isolated deposition predominantly in the automorphic soil of the Quaternary terraces. The geochemical association of the elements Tb-Dy-Ho-Er-Tm$\mathrm{Yb}-\mathrm{Lu}$ has a specific areal distribution in the environs of Bregalnica river and its tributaries. The anthropogenic influences that are related to the $\mathrm{Pb}$ $\mathrm{Zn}$ and $\mathrm{Cu}$ mineralization in the investigated area insignificantly influence the lithological distribution of this geochemical association. In the Maleševo valley, the Proterozoic felsic and mafic plutonites characterize the geological leading to dominant deposition of these elements. REEs can also be enriched during the soil-formation processses, even if the source material is not granitic rock [42]. On the other hand, in the Kočani valley the contents of HREEs above the 90th percentiles are mainly deposited on the Quaternary terraces while their occurrence is lower in the Rifeous shales. It is suggested [28] that the contents of these elements may be enriched by the intense application of phosphate fertilizers due to adjustment of these soils for growing rice (paddy soil).

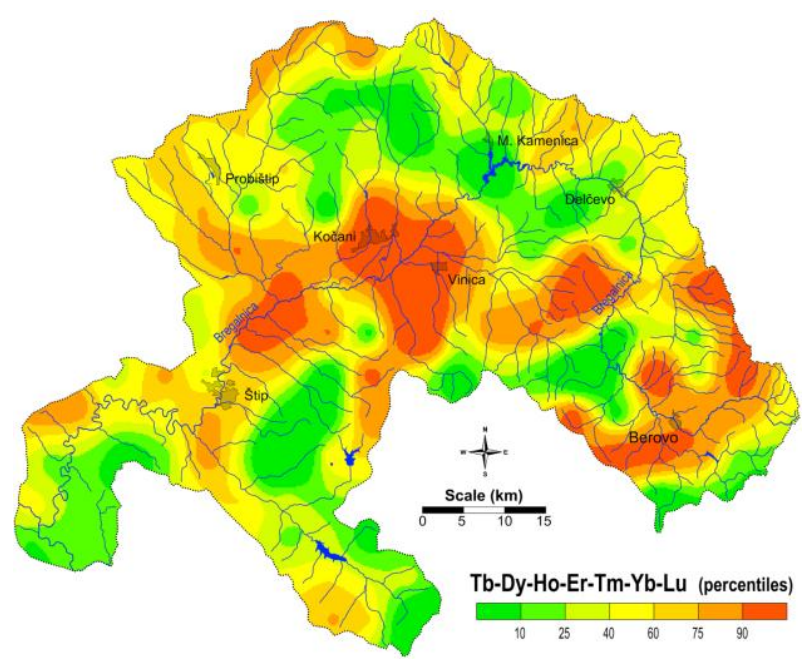

Fig. 6. Spatial distribution of Tb-Dy-Ho-Er-Tm-Yb-Lu in the investigated area

\section{CONCLUSION}

The distribution of the REEs in the Bregalnica river basin was examined based on automorphic and alluvial soil samples from 155 locations. The mean value of the sum total of rare earth elements ( $\Sigma$ REEs) was determined to amount to 79.3 $\mathrm{mg} \mathrm{kg}^{-1}$. The natural enrichment with REEs in the Bregalnica river environs can be detected on Quaternary terraces due to long-term sedimentation. The contents of LREEs were enriched in the areas with $\mathrm{Pb}-\mathrm{Zn}$ and $\mathrm{Cu}$ mineralization, where anthro- 
pogenic mining activities have been implemented for a long period of time. The basic geological formations related to this occurrence are the oldest metamorphic vulcanite rocks, Neogene and Paleogene volcanic sedimentary rocks, and the dominant Proterozoic gneiss. The HREEs (Tb-Dy-Ho-Er-Tm$\mathrm{Yb}-\mathrm{Lu})$ are deposited as a geochemical association predominantly in automorphic soil types on the terraces in the Bregalnica basin. The Bregalnica river environ is geochemically characterized by the archiving of the HREEs across the river terraces in the basins of the Maleševo and Kočani valleys.

Acknowledgements. This paper is a result of a research made possible by the financial support of the Sectoral Operational Programme for Human Resources Development 2007-2013, co-financed by the European Social Fund, under the project POSDRU/159/1.5/S/132400 - "Young successful researchers - professional development in an international and interdisciplinary environment".

\section{REFERENCES}

[1] X. D. Cao, X. R. Wang, G. W. Zhao, Assessment of the bioavailability of rare earth elements in soils by chemical fractionation and multiple regression analysis, Chemosphere, 40, 23-28 (2000).

[2] X. D. Cao, Y. Chen, X. R. Wang, X. H. Deng, Effects of redox potential and $\mathrm{pH}$ value on the release of rare earth elements from soil, Chemosphere, 44, 655-661 (2001).

[3] S. Zhang, X. Shan, Speciation of rare earth elements in soil and accumulation by wheat with rare earth fertilizer application, Environ. Pollut., 112, 395-405 (2001).

[4] C. Laveuf, S. Cornu, F. Juillot, Rare earth elements as tracers of pedogenetic processes, CR Geosci., 340, 523 $532(2008)$

[5] N. E. Holden, History of the Origin of the Chemical Elements and Their Discoverers. In: Prepared for the 41st IUPAC General Assembly, 29. June - 8. July 2001, Brisbane, Australia, 2001.

[6] P. H. Brown, A. H. Rathjen, R. D. Grahahm, D. E. Tribe, Rare earth elements in biological systems, In: K. A. Gschneidner Jr., L. Eyring (Eds.), Handbook on the Physics and Chemistry of Rare Earths, Elsevier Press, North-Holland, Amsterdam, Oxford, 1990.

[7] J. Riondato, F. Vanhaecke, L. Moens and R. Dams. Determination of rare earth elements in environmental matrices by sector-field inductively coupled plasma mass spectrometry, Fresen. J. Anal. Chem., 370, 544-552 (2001).

[8] G. Tyler, Rare earth elements in soil and plant systems. A review, Plant Soil, 267(1-2), 191-206 (2004).

[9] T. Möller. The Chemistry of the Lanthanides, Sisler, Reinhold Publishing Corporation, New York, London, 1963.

[10] X. K. Xu, W. Z. Zhu, Z. J. Wang, G. J. Witkamp, Distributions of rare earths and heavy metals in field- grown maize after application of rare earth-containing fertilizer, Sci. Total. Environ., 293, 97-105 (2002).

[11] T. Liang, S. Zhang, L. Wang, H. T. Kung, Y. Wang, A. $\mathrm{Hu}$, S. Ding, Environmental biogeochemical behaviors of rare earth elements in soil-plant systems, Environ. Geochem. Hlth., 27(4), 301-311 (2005).

[12] C. Laveuf, S. Cornu, L. R. G., Guilherme, A. Guerin, F. Juillot, The impact of redox conditions on the rare earth element signature of redoximorphic features in a soil sequence developed from limestone, Geoderma, 170, 25-38 (2012).

[13] X. Li, Z. Chen, Z. Chen, Zhang Y, A human health risk assessment of rare earth elements in soil and vegetables from a mining area in Fujian Province, Southeast China, Chemosphere, 93, 1240-1246 (2013).

[14] H. Y. Zhou, A. Greig, J. Tang, C. F. You, D. X. Yuan, X. N. Tong, Y. Huang, Rare earth element patterns in a Chinese stalagmite controlled by sources and scavening from karst groundwater, Geochim. Cosmochim. Acta, 83, 1-18 (2012).

[15] A. Kabata-Pendias, H. Pendias, Trace Elements in Soils and Plants. CRC Press, Boca Raton, London, New York, Washington D. C., 2001.

[16] S. Huang, D. Li, D. Wang, A. Peng, D. Wang, Species dynamic change of added rare earth element in soil, Huan Jing Ke Xue, 23(2), 117-119 (2002).

[17] S. Ding, Z. Zhang, T. Liang, Q. Sun, L. Zha, Effect of extraneous rare earths (REs) on form of soil exchangeable REs and heavy metals, Huan Jing Ke Xue, 24(4), 122-126 (2003).

[18] Z. K. Yuan, Y. Liu, H. Q. Yu, H. L. Zheng, N. F. Wang, M. K. Wu, Y. T. Liu, S. M. Yan, Study on relationship between rare earth level in blood and health condition of residents, Chin. Publ. Health, 19, 133-135 (2003).

[19] J. X. Li, M. Hong, X. Q. Yin, J. L. Liu, Effects of the accumulation of the rare earth elements on soil macrofauna community, J. Rare Earth, 28, 957-964 (2010).

[20] L. Meng, L. Ding, H. T. Chen, D. Q. Zhao, J. Z. Ni, Biological effect of rare earth (IV): Content and distribution of rare earth in normal human plasma. Chem. J. Chin. Univ., 20, 5-8 (1999).

[21] A. Lazarevski, Climate in Macedonia, Kultura, Skopje, 1993 (in Macedonian)

[22] Environment statistics. State Statistical Office, Skopje, 2013 (in Macedonian).

[23] T. Stafilov, B. Balabanova, R. Šajn, K. Bačeva, B. Boev. Geochemical atlas of Radovis and the environs and the distribution of heavy metals in the air, Faculty of Natural Sciences and Mathematics, Skopje, 2010.

[24] B. Balabanova, T. Stafilov, K. Bačeva, R. Šajn, Biomonitoring of atmospheric pollution with heavy metals in the copper mine vicinity located near Radoviš, Republic of Macedonia, J. Environ. Sci. Health Part A, 45, 1504-1518 (2010).

[25] B. Balabanova, T. Stafilov, R. Šajn, K. Bačeva, Distribution of chemical elements in attic dust as reflection of lithology and anthropogenic influence in the vicinity of 
copper mine and flotation, Archiv. Environ. Contam. Toxicol., 61, 173-184 (2011).

[26] B. Balabanova, T. Stafilov, R. Šajn, K. Bačeva, Characterization of heavy metals in lichen species Hypogymnia physodes and Evernia prunastri due to biomonitoring of air pollution in the vicinity of copper mine, Int. J. Environ. Res., 6, 779-794 (2012).

[27] B. Balabanova, T. Stafilov, R. Šajn, K. Bačeva, Spatial distribution and characterization of some toxic metals and lithogenic elements in topsoil and subsoil from copper mine environs, Int. J. Environ. Protect., 3, 1-9 (2013).

[28] N. Rogan, T. Serafimovski, M. Dolenec, G. Tasev, T. Dolenec. The distribution of rare earth elements (REEs) in paddy soil and rice seeds from Kočani Field (eastern Macedonia), RMZ - Mater.Geoenviron., 53(4) 433-444 (2006).

[29] N. R. Šmuc, T. Dolenec, T. Serafimovski, M. Dolenec, P. Vrhovnik, Geochemical characteristics of rare earth elements (REEs) in the paddy soil and rice (Oryza sativa L.) system of Kočani Field. Republ. Macedonia, Geoderma, 183, 1-11 (2012).

[30] R. Salminen, M. J. Batista, M. Bidovec, A. Demetriades, B. De Vivo, W. De Vos, M. Duris, A. Gilucis, V. Gregorauskiene, J. Halamič, P. Heitzmann, G. Jordan, G. Klaver, P. Klein, J. Lis, J. Locutura, K. Marsina, A. Mazreku, P. J. O'Connor, S. Å. Olsson, R. T. Ottesen, V. Petersell, J. A. Plant, S. Reeder, I. Salpeteur, H Sandström, U. Siewers, A. Steenfelt, and T. Tarvainen, Geochemical Atlas of Europe, Part 1, Background Information, Methodology and Maps. Geological Survey of Finland, Espoo, 2005.

[31] M. Olias, J. C. Ceron, I. Fernandez, J. D. Rosa, Distribution of rare earth elements in an alluvial aquifer affected by acid mine drainage: The Guadiamar aquifer (SW Spain), Environ. Pollut., 135, 53-64 (2005).

[32] T. Rakićević, N. Dumurdžanov, M. Petkovski, Basic Geological Map of SFRJ, sheet Štip, M 1:100,000 (map $\&$ interpreter), Federal Geological Survey, Belgrade, 1968.

[33] N. Dumurdžanov, T. Serafimovski, B. C. Burchfiel Evolution of the Neogene-Pleistocene basins of
Macedonia. Geological Society of America, Digital Map and Chart Series 1, (2004).

[34] B. Boev, Y. Yanev, Tertiary magmatism within the Republic of Macedonia: A review. Acta Vulcanologica, 13, 57-71 (2001).

[35] C. Reimann, P. Filzmoser, K. Fabian, K. Hron, M. Birke, A. Demetriades, E. Dinelli, A. Ladenberger, The concept of compositional data analysis in practice - Total major element concentrations in agricultural and grazing land soils of Europe, Sci. Tot. Environ., 426, 196-210 (2012).

[36] ISO 14869-1:2001, Soil quality - Dissolution for the determination of total element content. Part 1: Dissolution with hydrofluoric and perchloric acids. International Organization for Standardization, Geneva, Switzerland.

[37] G. E. P. Box, D. R. Cox, An analysis of transformations. J. R. Soc. Series B: Stat. Methodol., 26(2), 211-252 (1964).

[38] G. Žibret, \& R. Šajn, Hunting for geochemical associations of elements: Factor analysis and self-organizing maps. Math. Geoscie., 42, 681-703 (2010).

[39] H. J. M. Bowen, Environmental Chemistry of the Elements, Academic Press, London, UK, 1979.

[40] R. G. Garrett, Relative spatial soil geochemical variability along two transects across the United States and Canada, Appl. Geochem., 24, 1405-1415 (2009).

[41] E. Diatloff, C. J. Asher, F. W. Smith. Concentrations of rare earth elements in some Australian soils, A. J. Soil. Res., 34(5), 735-747 (1996).

[42] S. Yoshida, Y. Muramatsu, K. Tagami, S. Uchida, Concentrations of lanthanide elements, Th and $\mathrm{U}$ in 77 Japanese surface soil, Environ. Int., 24(3), 275-286 (1998).

[43] A. Wyttenbach, V. Furrer, P. Schleppi, L. Tobler, Rare Earth Elements in soil and in soil grown plants, Plant Soil, 199, 267-273 (1998).

[44] H. R. Rollinson, Using Geochemical Data: Evaluation, Presentation, Interpretation, Taylor \& Francis, London, UK, 2014. 